\title{
DIFFERENCES OF TOLERANCE CHARACTER PLANTING STRATEGIES RELIGIOUS INTEREST STUDENTS IN SDN INPRES 6.88 PERUMNAS 2 KOTA JAYAPURA
}

\author{
A. Arif Rofiki ${ }^{1}$ \\ Muliaty $\mathrm{Amin}^{2}$ \\ Susdiyanto $^{3}$ \\ Muh. Yusuf $\mathrm{T}^{4}$ \\ Islamic Institute of Fattahul Muluk Papua, Indonesia \\ Faculty of Da'wah and Communication UIN Alauddin Makassar, Indonesia ${ }^{2}$ \\ Faculty of Tarbiyah and Teacher Training UIN Alauddin Makassar, Indonesia ${ }^{3,4}$ \\ a.arifrofiki@gmail.com ${ }^{1}, \underline{\text { muliaty.amin@uin-alaudin.ac.id }}{ }^{2}$, susdiyanto@uin- $^{3}$ \\ alauddin.ac.id ${ }^{3}$, muh.yusuf@uin-alauddin.ac.id ${ }^{4}$
}

\begin{abstract}
This paper discusses the various strategies for cultivating the character of inter-religious tolerance in students of SDN Inpres 6.88 Perumnas 2 Kota Jayapura which is carried out through 1) school policies; 2) habituation to differences; 3 ) habituation to equations, and 4) group heterogeneity exercises. This research is field research. The research approach used in this research includes methodological (phenomenological) and scientific approaches (normative, juridical, and pedagogical theological approaches). The research method used was an interview, observation, and documentation. The results of this study indicate that the character of interreligious tolerance in students of SDN Inpres 6.88 Perumnas 2 Kota Jayapura is carried out through several strategies, namely: First, school policy. A strong commitment must be possessed by school policymakers in cultivating the character of tolerance between religious believers in students. This commitment is manifested in the inclusion of the character values of tolerance among religious believers in the mission, goals, and school regulations. Second, habituation to differences. The teacher accustoms students to differences from an early age. This is done by giving understanding to students to appreciate the differences that exist between them. Besides, in learning the teacher also trains students to appreciate differences of opinion when discussing. Third, habituation to equality. The teacher gives the understanding that all students have the same position in a school that is, both become students who have the same rights and obligations. Students when learning are accustomed to the teacher to see the similarities in meaning if there are different answers. . The teacher invites students to think from the same point of view, not from each student. Fourth, exercise heterogeneity in groups. The teacher gives group heterogeneity exercises to students in assigned group discussions during learning. The learning strategy used by the teacher in group discussion assignments is the cooperative learning strategy. Students work together in their study groups to complete the assignments the teacher has given them. Heterogeneity of study groups that favor cooperation can train and accustom students to learn to respect and tolerate differences that exist between themselves and their peers in terms of ethnicity, religion, social strata, or abilities.
\end{abstract}

Keywords: Character Planting; Tolerance; Jayapura City 


\section{INTRODUCTION}

Today there are many demands from various parties to improve the quality of character education in schools. This demand is based on a social phenomenon that is currently developing in the form of negative behavior among school-age children that can plunge the nation into destruction.

Character education is an effort to internalize the values of goodness into students so that they can manifest them in daily behavior. Character education is not limited to teaching the values of right and wrong to students but focuses more on cultivating and forming good habits in life so that students have awareness, understanding, concern, and high commitment to apply virtue in everyday life. ${ }^{1}$ Students who have strong individual and social characteristics are those who have good character, morals, and character. Given the urgency of character education, schools have the responsibility to instill it through the learning process.

Schools are still trusted by the community as an effective means of social transformation to instill strong character in children in addition to high competence. A strong character and high competence are the prerequisites for a strong identity and increased competitiveness of the nation to face the challenges of the 21 st century. One of these challenges is the openness of access to information globally which has implications for the transformation of negative foreign cultures that are incompatible with the values of national character. This has an impact on the moral decadence that is happening in the nation's children. Strengthening character education is considered relevant to overcome moral decadence that can destroy the nation in the future.

The glory or destruction of a nation depends on the quality of the character of its human resources. Efforts are needed to prepare young people who have strong characters so that they become superior human resources to welcome the future glory of the nation. This statement does not mean ignoring the urgency of cognitive and psychomotor competency aspects, but emphasizes the affective aspect, in the form of strong character. The destruction of the nation was not caused by the low quality of cognitive and psychomotor competencies of the nation's young generation, but due to the weak character possessed by them. If these ten signs, as stated by Lickona, occur among the younger generation of a nation, then that nation is on the verge of destruction in the future.

These signs also occur in the current generation of young Indonesians at school age, including elementary school (SD) children. There are several facts about the weak character of the nation's young generation who are still in elementary school, including drug abuse, violence between friends, murder, and sexuality.

A drug abuse case was committed by an elementary school student in Makassar, RK (12 years). He became a drug dealer and was wanted by the Tallo Police for a month. It was discovered that the police had become a drug dealer after the arrest of AR (14 years), a colleague who was still in Junior High School (SMP), because he was caught selling two packages of methamphetamine-type drugs in early August 2018. AR was ordered by RK to sell the 2 packages of crystal methamphetamine for Rp. 200,000, - which is divided in half according to their agreement. RK gave himself up after the police made a persuasive and understanding approach to his parents. After being examined by Tallo Police investigators, RK was deposited at the Integrated

${ }^{1}$ E. Mulyasa, Manajemen Pendidikan Karakter (Jakarta: PT. Bumi Aksara, 2013), h. 1-2. 


\section{Differences of Tolerance Character Planting Strategies Religious Interest Students in SDN Inpres 6.88 Perumnas 2 Kota Jayapura}

Service Center for the Empowerment of Women and Children (P2TP2A) in Makassar City. $^{2}$

The next fact is in the form of violence between friends experienced by AL ( 8 years old), an elementary school student in Gebog District, Kudus Regency, Central Java in July 2017 when she started school. He was subjected to physical violence in the form of slapping, beatings, and crushing the chest with a chair by nine fourth grade students at his school. It is suspected that the nine perpetrators of the violence were class gangs chaired by female students. ${ }^{3}$

Responding to the behavior of the younger generation which leads to the decadence of the nation's character, it is necessary to revitalize value education as an effort to build the nation's character. The urgency of character building is motivated by current national problems, including: (1) decreased understanding, appreciation, and practice of Pancasila values in everyday life; (2) decreasing quality of use of Indonesian language and love for domestic products; (3) low awareness of cultural diversity, historical values and local wisdom as well as respect for customs, traditions, and beliefs; (4) decreased fighting power and work culture (work ethic) as well as tolerance and tolerance for differences that can lead to social conflict; (5) strengthening of primordialism and fundamentalism values which could threaten the disintegration of the nation. ${ }^{4}$

One of the "blessings" the wealth of the Indonesian nation is the plurality of ethnicities, religions, races, and cultures. The plurality of this nation is likened to two sides of a coin. On the one hand, it can be used as a source of inspiration for the maturation of Indonesian democracy, but on the other hand, it has the potential to be used by irresponsible provocateurs as a trigger for the disintegration of the nation so that ethnic, religious and racial conflicts between groups can threaten the integrity of the Unitary State of the Republic of Indonesia (NKRI).

The multicultural society holds much positive strength from each group, as well as seeds of division if it is not managed properly and rationally. ${ }^{5}$ National and religious constructive potentials can develop positively if every child of the nation and religious community upholds the value of tolerance to establish harmony between religious communities. On the other hand, the destructive potential of the nation and religion can come to the surface of each of them does not uphold tolerance and harmony with the stigma that their religion is the truest, superior, and inferior to other religions. ${ }^{6}$

Therefore, to create a harmonious life/tolerance among religious believers, a concept of state life must be created that binds all members of social groups of different religions to avoid conflicts between religious believers.

\footnotetext{
${ }^{2}$ Hendra Cipto, "Kisah Murid SD Bandar Narkoba, Sebulan Jadi Buron Polisi", Kompas Online. 13 September 2018. https://regional.kompas.com/read/2018/09/13/07000091 (12 November 2018).

3 Akhmad Nazaruddin Lathif, "Kekerasan terhadap Siswa SD terjadi di Kudus", Antaranews.com, 31 Juli 2017. https://www.antaranews.com/berita/643693 (12 November 2018).

${ }^{4}$ Kementerian Pendidikan dan Kebudayaan, Rencana Strategis Kementerian Pendidikan dan Kebudayaan 2015-2019 (Jakarta: Kemendikbud, 2015), h. 24-25.

${ }^{5}$ H.A.R. Tilaar, Multikulturalisme, Tantangan-Tantangan Global Masa Depan dalam Transformasi Pendidikan Nasional (Jakarta: PT. Grasindo, 2004), h. 37.

${ }^{6}$ Alwi Shihab, Islam Inklusif: Menuju Sikap Terbuka dalam Beragama (Bandung: Mizan, 1997), h. 41 .
} 
Tolerance is a very valuable national character. It must continue to be nurtured in Indonesian society, especially in the present. Various events that occur in various regions due to factors of differences in ethnicity, religion, race, and class groups indicate the erosion of the character of tolerance in society. The character of tolerance can be eroded due to mutual suspicion among the nation's children. This erosion causes intolerant behavior which is marked by a lack of respect for one another.

Society of Papua is often identified with the behavior of violence and intolerance. The violence that occurred in several cases had political content, namely involving the State apparatus and the community, and communal violence that occurred between the communities. Meanwhile, the intolerant behavior committed by the Papuan people is more caused by the accumulation of various problems that are not resolved comprehensively. There have not been any cases of violence and intolerance with a religious background in Papua. Therefore, the campaign on the importance of inter-religious tolerance needs to be encouraged by policymakers to maintain interreligious tolerance which has been well established in Papua, which has a plurality of religions in its people.

Although efforts to instill the character of tolerance between religious believers have been carried out through educational institutions in Indonesia, there are still some educational institutions that ignore the importance of cultivating the character of tolerance between religious believers in their students. This is evidenced by the fact that there is still intolerant behavior in educational institutions. One of the factual cases that have occurred is the behavior of intolerance at Entrop SDN Jayapura, Papua. A student is sent home by the school during the learning process because he is wearing a headscarf at school. ${ }^{7}$

The student with the initials FD was kicked out twice by the school principal, namely on Thursday, 14 August, and Saturday, 16 August 2014. The grade 5 student immediately returned home because of the act of expulsion. FD's parents think that there is nothing wrong with wearing a headscarf at school because the school is a public school. Meanwhile, the Head of SDN Entrop, Barsalina Hamadi, denied the expulsion of FD. He assumed that all students must comply with school regulations regarding the wearing of uniforms. Meanwhile, in the regulations for wearing uniforms that are applied in her school, there is no item on wearing a veil for female students. The school then gave a letter of recommendation to change schools to FD's to attend an educational institution that allowed their students to wear a headscarf.

The case of intolerance committed by SDN Entrop Kota Jayapura indicates that there is still discriminatory behavior against minorities. Such behavior must be eliminated to create inter-religious tolerance which has implications for the creation of inter-religious harmony in Indonesia. If intolerant behavior between religious believers still exists among the nation's children, then inter-religious harmony in Indonesia will become fragile and can threaten the unity and integrity of the nation.

This paper discusses the various strategies for cultivating the character of interreligious tolerance in students of SDN Inpres 6.88 Perumnas 2 Kota Jayapura which is carried out through 1) school policies; 2) habituation to differences; 3) habituation to equations, and 4) group heterogeneity exercises.

${ }^{7}$ Rivando Nay, "Sekolah Negeri di Papua Larang Siswi Pakai Kerudung”, Sindonew.com, 21 Agustus 2014. https://daerah.sindonews.com/read/893817/26/sekolah-negeri-di-papua-larang-siswi-pakaikerudung-1408626778 (12 November 2018). 


\section{Differences of Tolerance Character Planting Strategies Religious Interest Students in SDN Inpres 6.88 Perumnas 2 Kota Jayapura}

\section{THEORETICAL STUDY}

Character education was formulated by Dony Koesoema, quoted by Zubaedi, that character education is a dynamic development of continuous abilities in humans to internalize values to produce an active and stable disposition. These dynamics make individual growth more complete. These elements become dimensions that animate the formation process of each individual. ${ }^{8}$

This opinion can be understood that character education is education that develops the values of each individual to have noble character values in him, by applying these values to his life as a citizen and as a good citizen. Character education can also be interpreted as all the efforts made by the teacher that can affect the character of students. Teachers are expected to be able to shape students through exemplary, the way teachers speak when delivering tolerant material, and various things related to it.

Thus, character education can be concluded as all efforts made deliberately by adults to implement character values in individuals, so that they become humans who think mature, have a strong mentality so that they can face existing problems, have personality, and behave well. According to religious norms which are manifested in interactions with God, oneself, and fellow humans.

For character education in all formal education institutions, according to the former President of the Republic of Indonesia, Susilo Bambang Yudhoyono, there are at least five basic goals in the need to provide character education as follows: 1) Forming a moral human being; 2) Forming intelligent and rational Indonesian people ; 3) Forming innovative and hardworking Indonesian people; 4) Forming human beings who are optimistic and confident, and 5) Forming Indonesian people who have patriot spirit or a principle of fostering an attitude of love for the country. ${ }^{9}$

While the guidelines for the implementation of character education are sourced from the Ministry of National Education, character education aims to develop the values that shape the character of the nation, namely Pancasila, including 1) Developing the potential of students to become humans who have hearts, minds, and good behavior; 2) Building a nation with the character of Pancasila; and 3) Developing the potential of citizens to have an attitude of confidence, pride in their nation and country, and to love humanity. ${ }^{10}$

In the description above, it can be concluded that character education aims to shape humans to become more intelligent in the context of self-development as learning beings. Character education also aims to form a complete Indonesian human figure, namely a person with character, innovative, hard-working, self-confident, to form a responsible leadership spirit, to have mental toughness so as not to fall into deviant or contrary behavior to Islam. Apart from goals, character education also has a function by the function of National education. The Ministry of National Education in the Master Design for Character Education explained or explained that character education is intended to develop the capacity or ability and shape the character and

\footnotetext{
${ }^{8}$ Zubaedi, Desain Pendidikan Karakter: Konsepsi dan Aplikasinya pada Lembaga Pendidikan, h. 19.

${ }^{9}$ Nurla Isna Aunillah, Panduan Menerapkan Pendidikan Karakter di Sekolah, h. 97.

${ }^{10}$ Kementerian Pendidikan Nasional, Panduan Pelaksanaan Pendidikan Karakter (Jakarta: Kemendiknas, 2011), h. 7.
} 
civilization of a nation that is advanced, superior, and dignified to educate the lives of the nation's children. ${ }^{11}$

Among the characters that must be internalized in students is the character of tolerance. tolerance is an attitude or behavior of respect, giving freedom, gracefulness, and respecting differences to others. The difference is a necessity given by God to humans. A tolerant person will respect these differences by not imposing their will on others, giving them the freedom to do and practice what they believe, accept these differences gracefully, and respect the choices of others even though they are different from themselves without sacrificing their principles.

There are two interpretations of the meaning of tolerance in the concept, namely: First, negative tolerance. The point is that tolerance simply requires an attitude of letting and not hurting other people or groups who are different or the same as him. Second, tolerance is positive. ${ }^{12}$ The point is that tolerance is not enough just to let and not hurt other people or groups, but there must be help and support for the existence of other people or groups.

Tolerance associated with religion and belief means respect, allowance, and allow for differences in religion and belief. Tolerance does not mean that someone has to give up their religion and beliefs because of differences with others, but allows those differences to remain. The study of tolerance among religious believers was first examined by John Locke in the context of the relationship between the church and the state in England. ${ }^{13}$ Tolerance is defined as a willingness not to interfere in the beliefs, attitudes, and actions of others, especially those who are disliked. The state is not allowed to interfere in religious matters and is not allowed to be handled by certain religious groups.

Tolerance between religious believers in the Indonesian National Encyclopedia is defined as being willing to accept the diversity and freedom of religion that is held and the beliefs that are believed by other parties or groups. ${ }^{14}$ This attitude can be realized because of the recognition and respect of one party for the existence and existence of a group, religion, or belief of another party. Respect and recognition are not only limited to equality in the state, social, and in front of God Almighty but also differences in the ways of living and worshiping them based on fair and civilized human values. So tolerance between religious believers is an attitude of patience and restraint from disturbing and harassing religions, beliefs, and worship of followers of other religions.

Differences are not used as an excuse to be mutually hostile and contradictory, because it is a necessity from God for His creatures on this earth that cannot be rejected by anyone. This principle implies the agreement of all religions to live in harmony while maintaining the existence of all religions. Thus, tolerance between religious believers is not just a passive coexistence without any involvement and cooperation with one another, but more than that, namely active and dynamic

\footnotetext{
${ }^{11}$ Kementerian Pendidikan Nasional, Desain Induk Pendidikan Karakter (Jakarta: Kemendiknas, 2010), h. 5 .

${ }^{12}$ Masykuri Abdullah, Pluralisme Agama dan Kerukunan dalam Keragaman (Jakarta: Penerbit Buku Kompas, 2001), h. 13.

${ }^{13}$ Tim Penyusun, Ensiklopedi Nasional Indonesia Jilid XVI (Jakarta: Cipta Adi Pustaka, 1996), h. 384.

14 Compilation Team, Indonesian National Encyclopedia Volume XVI (Jakarta: Cipta Adi Pustaka, 1996 ), p. 384
} 


\section{Differences of Tolerance Character Planting Strategies Religious Interest Students in SDN Inpres 6.88 Perumnas 2 Kota Jayapura}

tolerance. Actualization is a relationship of mutual respect and appreciation, doing good and fairness between one another, and working together in the development of a harmonious, harmonious, and peaceful society.

In line with this definition, according to Said Agil Munawar, there are two kinds of tolerance between religious believers: first, static tolerance between religious believers, namely cold tolerance which does not create cooperation, only static. Second, dynamic tolerance between religious believers, namely active tolerance that creates cooperation to achieve common goals for the creation of harmony between religious believers in the framework of togetherness of religious communities as one nation. ${ }^{15}$ Active tolerance is the teaching of all religions. The essence of tolerance is to live side by side in peace and mutual respect among diversity. Tolerance practices in a country often experience ups and downs. The ups and downs are triggered by a distinctive meaning that rests on the relationship between "them" and "us". ${ }^{16}$

Religious tolerance which is carried out with full awareness will give birth to an inclusive attitude of religious communities. This attitude considers religion itself to be right but still provides room to state the truths of other religions that are believed to be true by its followers. The inclusive attitude of religious communities will be able to undermine the extremist and exclusive attitudes of religious communities, which usually give birth to blind fanatical understanding and radicalism and even lasting terrorism against people of different religions.

Tolerance simply requires an attitude of letting go and not hurting other people or groups, both different and the same. Tolerance is grown by an awareness that is free from all forms of pressure or influence and is protected from hypocrisies. Tolerance contains the intention of enabling the formation of a system that ensures the safety of personal, property, and minority elements in society. This is realized by respecting religion, morality, and their institutions and respecting the opinions of others and the differences that exist in their environment without having to disagree with others just because of different beliefs or religions. About religion, tolerance includes issues of belief in humans that are related to faith or which are related to the divinity they believe in. A person must be given the freedom to believe in and embrace the religion (having a creed) of each one he chooses and to pay respect for the implementation of the teachings he or she believes in.

\section{III.RESEARCH METHODOLOGY}

This research is field research. The research approach used in this research includes methodological (phenomenological) and scientific approaches (normative, juridical, and pedagogical theological approaches). The research method used was an interview, observation, and documentation.

\section{IV.RESULT AND DISCUSSIONS}

The results of observation, interviews, and supported by related documents show several findings of various strategies for cultivating the character of tolerance among religious believers in students of SDN Inpres 6.88 Perumnas 2 Kota Jayapura.

17.

${ }^{15}$ Said Agil Husni Al-Munawar, Fikih Hubungan Antar Agama (Jakarta: Ciputat Press, 2003), h.

${ }^{16}$ Casram, "Membangun Sikap Toleransi Beragama dalam Masyarakat Plural”, h. 191. 
Researchers analyzed various strategies for cultivating the character of tolerance between religious believers from the aspects of the principal's policies and the efforts made by the teacher in cultivating the character of tolerance between religious believers in the classroom. The following is a description of the various strategies for cultivating the character of tolerance between religious believers in students of SDN Inpres 6.88 Perumnas 2 Kota Jayapura.

\section{A. School Policy}

Based on the results of interviews with school principals, it is known that policies related to the strategy of cultivating the character of tolerance among religious believers have been established. At the time of the interview, the principal said the following:

"The vision of SDN Inpres 6.88 Perumnas 2 City of Jayapura for the 2018/2019 academic year is "Forming students who are faithful, have a noble character, and excel in achievement, and love the environment". The character of winning tolerance is not written concretely in the school's vision, sir, but in the school's mission number three there is a policy on character education for tolerance between religious believers, namely: "Developing habituation learning to foster noble character attitudes". Tolerance between religious believers is an example of a noble character." 17

Based on the principal's narrative, it can be seen that the school has established a vision related to tolerance even though it is not explicitly written. Even though the school's vision does not include things related to tolerance, in one of the school's missions it is aimed at the character of tolerance between religious believers. This can be seen from the number three mission sentence of the school, namely: "Developing habituation learning to foster noble character attitudes". Tolerance between religious believers is one of the manifestations of the noble character attitudes of students.

The same thing was also expressed by Kristina P. Parirak, S.Pd. The following is his narrative:

"If the vision of the school itself does not show the character of tolerance among various believers, sir, but in its mission, there is one that contains tolerance among religious believers, namely: "Developing habituation learning to foster noble moral attitudes". In my opinion, the meaning of the sentence contains about tolerance between religious believers, because it is one of the examples of noble character." 18

This was reinforced by the results of the analysis of curriculum documents conducted by researchers. The results of the curriculum analysis show that in the curriculum at SDN Inpres 6.88 Perumnas 2 Kota Jayapura, there is no school vision of the character of tolerance among religious believers as expressed by the principal and teachers interviewed. Meanwhile, in the school mission, there is a description of

\footnotetext{
${ }^{17}$ Diana Lumban Gaol (55 tahun), Kepala SDN Inpres 6.88 Perumnas 2 Kota Jayapura, Wawancara, Jayapura, 25 Maret 2019.

${ }^{18}$ Kristina P. Parirak (40 tahun), Guru Kelas 5 C SDN Inpres 6.88 Perumnas 2 Kota Jayapura, Wawancara, Jayapura, 25 Maret 2019.
} 


\section{Differences of Tolerance Character Planting Strategies Religious Interest Students in SDN Inpres 6.88 Perumnas 2 Kota Jayapura}

tolerance between religious believers which is the meaning of examples of noble character traits.

Based on the description above, it can be concluded that in the vision of SDN Inpres 6.88 Perumnas 2 Kota Jayapura, there is no explicit character of tolerance between religious believers. The value of the character of tolerance among religious believers appears in the third school mission implicitly. The editorial team of the school's mission-related to the character of tolerance between religious believers is: "Developing habituation learning to foster noble moral attitudes". The character of tolerance between religious believers is integrated into noble moral attitudes.

Furthermore, these missions were translated into more practical goals. As for the narrative of the principal Diana Lumban Gaol, M.Pd. related to school goals are as follows:

"Yes sir. The purpose of the school related to inter-religious tolerance is found in the first point, namely "Carrying out worship by the religion adopted to realize faith and piety towards God Almighty"."19

Based on the narrative of the principal, it can be seen that among the school goals formulated, there are points that include the character of tolerance among religious believers. This is reinforced by the statement of Mrs. Kristina P. Parirak, S.Pd. as follows:

"In the school's purpose, there is a pack, namely: "Carrying out worship by the religion adopted to realize faith and piety towards God Almighty"."20

To prove the truth of the interview, the researcher analyzed the curriculum documents relating to school objectives. The results of the analysis of the curriculum documents show that in the school objectives there are things related to the character of tolerance as conveyed by the principal and teachers who were interviewed.

Based on this description, it can be seen that in the school objectives in the first point, the character of tolerance between religious believers is listed. The purpose of the school is "Carrying out worship by the religion adopted to realize faith and piety towards God Almighty". The implementation of worship by the religion adopted is one indicator of the character of tolerance among religious students of SDN Inpres 6.88 Perumnas 2 Kota Jayapura.

Next, the researcher asked about school regulations to the principal. When asked about school regulations, school principal Diana Lumban Gaol, M.Pd. convey the following:

"There are also school rules. In every class, there are rules for students, sir. These rules are installed in each class, pack, one of which is that students are asked to maintain $10 \mathrm{~K}$ which stands for Faith, Health, Cleanliness, Security, Order, Beauty, Kinship, Shelter, Openness, and Alertness." 21

\footnotetext{
${ }^{19}$ Diana Lumban Gaol (55 tahun), Kepala SDN Inpres 6.88 Perumnas 2 Kota Jayapura, Wawancara, Jayapura, 25 Maret 2019.

${ }^{20}$ Kristina P. Parirak (40 tahun), Guru Kelas 5 C SDN Inpres 6.88 Perumnas 2 Kota Jayapura, Wawancara, Jayapura, 25 Maret 2019.

${ }^{21}$ Diana Lumban Gaol (55 tahun), Kepala SDN Inpres 6.88 Perumnas 2 Kota Jayapura, Wawancara, Jayapura, 25 Maret 2019.
} 
Furthermore, the researcher asked the relevance of these regulations to the character of tolerance among religious believers. The following are the responses given by the principal:

We, teachers, hope that tolerance will emerge when students maintain kinship among them, sir. Every child certainly has a different character and thinking. Therefore, to maintain class harmony and kinship, students are expected to be able to develop a character of tolerance between religious believers amid religious differences that exist between them. ${ }^{22}$

The statement of the principal shows that the rules are made to train students to have a character of tolerance among religious believers in themselves and are expected to be internalized within themselves. Thus, students can maintain togetherness and kinship in the class. The class atmosphere will be harmonious if every class member respects each other.

Furthermore, researchers conducted interviews with teachers regarding school regulations relating to tolerance. The following is the response given by Mrs. Kristina P. Parirak, S.Pd.

"If there are school rules posted in every class, sir, and especially my class, 5 $\mathrm{Cs}$, there are rules displayed at the back of the class, sir. There are 8 regulations, sir, but the last rule referring to the character of tolerance among religious believers is to maintain the $10 \mathrm{~K}$."

This is reinforced by the statements of the two students who the researchers interviewed, namely Britney and Tamariska, who stated that in the classroom there are rules related to tolerance.

Furthermore, researchers analyzed disciplinary documents displayed in class. Based on this analysis, it is known that in the classroom there are rules related to tolerance. The rules read: Take part in maintaining the 10K (Faith, Health, Cleanliness, Security, Order, Beauty, Kinship, Shelter, Openness, and Vigilance). For more details, the following authors describe the school regulations:

School Rules:

a. Be there 5 minutes before the lesson starts.

b. Dress clean and tidy.

c. Pray.

d. Be polite towards teachers and between students.

e. Turning off the cellphone during class hours.

f. Not allowed to damage existing plants in school.

g. The picket officer must arrive early.

h. Participate in maintaining the 10K (Faith, Health, Cleanliness, Security, Order, Beauty, Kinship, Shelter, Openness, and Alertness).

Based on the description of school rules, there are points about the character of tolerance between religious believers, which are listed in the eighth point.

\footnotetext{
${ }^{22}$ Diana Lumban Gaol (55 tahun), Kepala SDN Inpres 6.88 Perumnas 2 Kota Jayapura, Wawancara, Jayapura, 25 Maret 2019.
} 


\section{Differences of Tolerance Character Planting Strategies Religious Interest Students in SDN Inpres 6.88 Perumnas 2 Kota Jayapura}

Based on the triangulation of sources and cross-check between the results of interviews and the results of document analysis, it can be seen that in school regulations there are things that are related to the character of tolerance between religious believers. This is stated in student code number eight which reads "Take part in maintaining 10K (Faith, Health, Cleanliness, Security, Order, Beauty, Kinship, Shelter, Openness, and Vigilance). One of the purposes of this discipline is to educate students to maintain kinship between students. To maintain this kinship, students are expected to be able to appreciate the differences that exist between students to create harmony and respect one another.

Based on the description above, it can be concluded that one of the strategies for cultivating the character of tolerance between religious believers in students of SDN Inpres 6.88 Perumnas 2 Kota Jayapura is through school policy. In school policy, the character of tolerance between religious believers is included in the school's mission. Besides, the character of tolerance between religious believers is also included in the school's goals and regulations.

School policies and regulations relating to the strategy of cultivating the character of tolerance among religious believers are one of the implementations of school culture, namely a culture of tolerance. School culture has a broad scope, including rituals, expectations, relationships, demographics, curricular activities, extracurricular activities, decision-making processes, policies, and social interactions between components in schools. School culture is the atmosphere of school life where students interact with each other, teachers and teachers, counselors with each other, administrative staff with each other, and among members of the school community. Internal group and inter-group interactions are bound by various rules, norms, morals, and common ethics that apply in a school.

\section{B. Habits Against Differences}

Based on the results of interviews with school principals, it is known that teachers instill the character of tolerance between religious believers through accustoming students to differences from an early age. The following is the principal's response to the efforts to familiarize students with differences:

"Yes, sir told. Every student has a different religion. Therefore we accustom students to appreciate the religious differences that exist between them, sir." ${ }^{23}$

Based on this explanation, it can be seen that the principal trains students to see differences from an early age by providing the understanding that students have different religions, personalities, and traits. Therefore students are educated to respect the religious differences that exist between them.

A similar opinion was also expressed by Mrs. Yulius Pius Nainggolan, S.Pd. related to the habituation of students to differences from an early age. The following is the response of Mrs. Yulius Pius Nainggolan, S.Pd. related to the researcher's question about how teachers train students to see differences from an early age.

${ }^{23}$ Diana Lumban Gaol (55 tahun), Kepala SDN Inpres 6.88 Perumnas 2 Kota Jayapura, Wawancara, Jayapura, 26 Maret 2019. 
"Yes, one of them is by explaining to them, that each student has different potential from the others. For example, B, he is good at mathematics, he is not necessarily good in other fields. Likewise you, maybe you are lacking in Mathematics, but you are good at other learning materials. Therefore, don't be jealous of other friends, because your potential is different." 24

Based on the narrative of Mrs. Yulius Pius Nainggolan, S.Pd. In this regard, it can be seen that the teacher trains students to appreciate the differences in their potential by providing understanding to students to appreciate the differences that exist between them. Furthermore, Robin and Andi, grade 5 A students, also revealed that when discussing, they were trained to respect other people's opinions.

This statement is strengthened by the results of observations in class $5 \mathrm{C}$ on March 26, 2019, which show that in thematic learning on theme 8 (Ecosystem), subtheme 1: Ecosystem Components, learning 3 in Indonesian material the teacher invites students to see the similarities in the meaning of sentences written by each group using different sentences. Whereas in the PPKn material, the teacher asks students to discuss in small groups about the interaction experience of students with friends or relatives of different ethnicities, religions, and races. Then they presented their interesting experiences in front of the class.

On March 27, 2019, in lesson 4 on the PPKn material the teacher gave students the assignment to discuss a question about how to respond to differences with friends at school? Even though the sentences used to answer are different, they have the same meaning. Meanwhile, in social studies material, students are asked to discuss the motto of Bhinneka Tunggal Ika. The results of the discussion are then presented to the class. Even though the style of a presentation displayed is different, the meaning they want to convey is the same.

Based on the triangulation of sources and cross-check between the results of the interview and the results of the observations that have been described, it can be seen that the teacher accustoms students to differences from an early age. This is done by giving understanding to students to appreciate the differences that exist between them. Also, in learning the teacher trains students to appreciate differences of opinion when discussing.

With an understanding of the differences that students have and habituation to differences in their learning activities, it can make students appreciate the differences that exist between them. Teachers at SDN Inpres 6.88 Perumnas 2 Kota Jayapura familiarize students with seeing differences from an early age by understanding the differences in their potential. Students certainly have different potentials in themselves. There are those whose potential is prominent in the academic field, there are also students whose potential is less prominent in the academic field. The teacher asks students to appreciate the potential differences that students have. They understand that the difference doesn't matter. The difference is not a gap between one person and another, precisely with the difference the world will feel more beautiful. With differences, students can get to know more about the diversity that exists between them. This can raise awareness for students outside of themselves, many people are different from themselves. Thus, awareness of differences is expected to

${ }^{24}$ Yulius Pius Nainggolan (35 tahun), Guru Kelas 5 A SDN Inpres 6.88 Perumnas 2 Kota Jayapura, Wawancara, Jayapura, 26 Maret 2019. 


\section{Differences of Tolerance Character Planting Strategies Religious Interest Students in SDN Inpres 6.88 Perumnas 2 Kota Jayapura}

strengthen the character of tolerance among religious students to appreciate the differences that exist between them.

\section{Habits Against Eq}

Based on the results of interviews with school principals, it is known that the principal also accustoms students to equality. Following is the principal's narrative regarding the principal's efforts in accustoming students to equality.

"Yes sir. We give understanding to children that their position in the school is the same, that is, they are both students. We provide equal opportunities for all students to learn and mingle with peers at school. We also pay special attention to underprivileged students, sir. So we are helping underprivileged students through scholarships so that they can be used to buy school supplies. We want underprivileged students to also have adequate facilities for the school."25

Based on the statement of the principal, it can be seen that the principal gives understanding to students that all students have the same position in school, that is, they are both students.

This is in line with the opinion of Mrs. Yulius Pius Nainggolan, S.Pd. The following is her explanation regarding the efforts to train students to familiarize themselves with equality.

"I give understanding to students that the position of children in school is the same, that is, they are equally students. It is only possible that the potential between students is different, some are caused by heredity and some are caused by the nature of the students themselves. Some students are lazy and there are diligent students. That is what causes differences between students. Even so, students both have their potential. If there are differences in their answers during a discussion, I always ask them to see the similarities in the meanings of the answers." 26

Based on the narrative of Mrs. Yulius Pius Nainggolan, S.Pd. In this regard, it can be seen that the teacher trains students to always see the similarities of the differences in students' answers to the tasks given by the teacher in learning. Furthermore, Robin and Andi, students in grade $5 \mathrm{~A}$, also revealed that when discussing, they were trained to see the similarity of meaning from each of their friends' answers.

This statement is strengthened by the results of observations in class $5 \mathrm{C}$ on March 26, 2019, which show that in thematic learning on theme 8 (Ecosystem), subtheme 1: Ecosystem Components, learning 3 in Indonesian material the teacher invites students to see the similarities in the meaning of sentences written by each group using different sentences. Whereas in the PPKn material, the teacher asks students to discuss in small groups about the interaction experience of students with friends or relatives of different ethnicities, religions, and races. Then they presented their interesting experiences in front of the class. After the presentation, students were asked to

\footnotetext{
${ }^{25}$ Diana Lumban Gaol (55 tahun), Kepala SDN Inpres 6.88 Perumnas 2 Kota Jayapura, Wawancara, Jayapura, 26 Maret 2019.

${ }^{26}$ Yulius Pius Nainggolan (35 tahun), Guru Kelas 5 A SDN Inpres 6.88 Perumnas 2 Kota Jayapura, Wawancara, Jayapura, 26 Maret 2019.
} 
conclude the similarities in meaning between the results of their friends' interesting experiences that had been presented.

On March 27, 2019, in lesson 4 on the PPKn material the teacher gave students the assignment to discuss a question about how to respond to differences with friends at school? Although the sentences used to answer are different, they have the same meaning. Students are then instructed to conclude about the existing equations from the answers that have been submitted by their friends. Meanwhile, in the social studies material, students are asked to discuss the motto of Bhinneka Tunggal Ika. The results of the discussion are then presented to the class. Even though the style of a presentation displayed is different, the meaning they want to convey is the same. Students are then instructed to conclude about the existing equations from the answers that have been presented by their friends.

Based on the triangulation of sources and cross-check between the results of the interviews and the results of the observations, it is known that the principal and teachers of SDN Inpres 6.88 Perumnas 2 Kota Jayapura instill the character of interfaith tolerance of students through acclimation to the equations that exist between them. The teacher gives the understanding that all students have the same position in a school that is, both become students who have the same rights and obligations. Also, in learning the teacher invites students to see the similarities in meaning if their answers are different.

Everyone certainly has their point of view in responding to something, as well as students. Therefore, the teacher acts as a mediator among students to translate the differences in opinions and views of students to achieve a common thought. To instill the character of tolerance between religious believers in students, the teacher helps students see the similarities between them. The teacher said that each child had the same potential. It's just that, the potential of students is not the same. This is done by the teacher so that students do not envy each other's abilities because students also have their respective potential. In learning, the teacher also invites students to look for similarities if there are different opinions from them. The teacher invites students to think from the same point of view, not for each student. Besides students being accustomed to differences, they are also accustomed to seeing differences as something beautiful; they are also helped to see their similarities with other friends. By helping students see similarities, they will appreciate the abilities that exist in him. Besides, seeing the similarities of students with other friends will also help students get rid of their jealousy towards others. The teacher's efforts to help students see their similarities with others are carried out continuously to develop the character of tolerance between religious believers in students.

\section{Group Heterogeneity Exercises}

Based on the results of interviews with the principal, it is known that the principal also provides heterogeneity training in groups of students. Following is the principal's narrative relating to the principal's efforts to exercise heterogeneity in groups of students.

"Yes sir. We always make it a habit for our children to hang out with their friends regardless of their ethnicity and religion. Routine activities Tuesday morning English Day, Wednesday morning memorizing multiplication, Thursday morning silent reading, and Friday morning exercise together, 


\section{Differences of Tolerance Character Planting Strategies Religious Interest Students in SDN Inpres 6.88 Perumnas 2 Kota Jayapura}

students are united regardless of ethnicity and religion. They used to group heterogeneously in these activities." 27

Based on the statement of the principal, it can be seen that the principal accustoms to heterogeneity in groups of students in routine morning activities before learning. Students carry out activities into a heterogeneous group in terms of ethnicity and religion.

This is in line with the opinion of Mrs. Yulius Pius Nainggolan, S.Pd. The following is her explanation regarding the effort to practice heterogeneity in groups.

"In the group discussion learning method, I make students in groups in which the members are heterogeneous in terms of both ethnicity and religion. I have made them a habit so that they can accept differences and be able to work together on the differences that exist between them." 28

Based on the narrative of Mrs. Yulius Pius Nainggolan, S.Pd. It can be seen that the teacher gives group heterogeneity exercises to students in group discussion assignments during learning. Furthermore, Robin and Andi, students in grade $5 \mathrm{~A}$, also revealed that when discussing, they were always grouped into groups of different ethnic and religious members.

This statement is strengthened by the results of observations in class $5 \mathrm{C}$ on March 26, 2019, which show that in thematic learning on theme 8 (Ecosystem), subtheme 1: Ecosystem Components, learning 3 in Indonesian and PPKn material, the teacher divides the groups into 6 groups. Each group has members of 5 students (there are 2 groups) and 6 students (there are 3 groups) of the total number of students in class $5 \mathrm{C}$, namely 33 students. Each group has members from different ethnic and religious backgrounds. Students work together in groups to make questions about the reading theme "Society as One of the Ecosystem Components" in Indonesian language material and discuss the interaction experiences of students with friends or relatives of different ethnicities, religions, and races from them on the PPKn material.

On March 27, 2019, in lesson 4 on PPKn and Social Studies material the teacher divided the groups into 6 groups. Each group has members of 5 students (there are 2 groups) and 6 students (there are 3 groups) of the total number of students in class $5 \mathrm{C}$, namely 33 students. Each group has members from different ethnic and religious backgrounds. Students work together in groups to discuss a question about how to respond to differences with friends at school on PPKn material and discuss the motto of Bhinneka Tunggal Ika on IPS material.

Based on source triangulation and cross-check between the results of the interview and the results of the observations, it is known that the principal and teachers of SDN Inpres 6.88 Perumnas 2 Kota Jayapura instill the character of interfaith tolerance of students through heterogeneity training in groups. The teacher gives group heterogeneity exercises to students in assigned group discussions during learning. The learning strategy used by the teacher in group discussion assignments is

\footnotetext{
${ }^{27}$ Diana Lumban Gaol (55 tahun), Kepala SDN Inpres 6.88 Perumnas 2 Kota Jayapura, Wawancara, Jayapura, 26 Maret 2019.

${ }^{28}$ Yulius Pius Nainggolan (35 tahun), Guru Kelas 5 A SDN Inpres 6.88 Perumnas 2 Kota Jayapura, Wawancara, Jayapura, 26 Maret 2019.
} 
the cooperative learning strategy. Students work together in their study groups to complete the assignments the teacher has given them.

Study groups that promote cooperation can form the character of interfaith tolerance of students at SDN Inpres 6.88 Perumnas 2 Kota Jayapura. Heterogeneity of study groups that favor cooperation can train and accustom students to learn to respect and tolerate differences between themselves and their friends in terms of ethnicity, religion, social strata, or abilities. Learn to work with others more effectively, and to acquire more academic knowledge and skills. Thus cooperative learning reinforces the main civic values.

Students of SDN Inpres 6.88 Perumnas 2 Kota Jayapura have a plurality of religions, namely Islam, Christianity, and Catholicism. The teacher responded to this plurality by instilling a character of tolerance between religious believers in students. One of the methods used by the teacher is to provide heterogeneity training in groups during learning. Through these exercises students are educated to accept and appreciate the differences that exist, even to cooperate with others without being hindered by these differences. The tolerance implanted in SDN Inpres 6.88 Perumnas 2 Kota Jayapura is not only static and passive but dynamic active tolerance. Passive static tolerance that is cold does not give rise to cooperation, while dynamic active tolerance will give birth to cooperation so that harmony in life between religious believers can be realized as a reflection of the togetherness of religious communities and not just a theory.

\section{CLOSING}

Based on the above, it can be concluded that the character of religious tolerance among students of SDN PI 6.88 2 Jayapura City Housing is done through several strategies, namely: First, the school policy. A strong commitment must be possessed by school policymakers in cultivating the character of tolerance between religious believers in students. This commitment is manifested in the inclusion of the character values of tolerance among religious believers in the mission, goals, and school regulations. Second, habituation to differences. The teacher accustoms students to differences from an early age. This is done by giving understanding to students to appreciate the differences that exist between them. In learning the teacher also trains students to appreciate differences of opinion when discussing. Understanding the differences that students have and habituation to differences in their learning activities can make students appreciate the differences that exist between them. Third, habituation to equality. The teacher gives the understanding that all students have the same position in school, which is, both become students who have the same rights and obligations. Students when learning is accustomed to the teacher to see the similarities in meaning if there are different answers. The teacher invites students to think from the same point of view, not for each student. Fourth, exercise heterogeneity in groups. The teacher gives group heterogeneity exercises to students in assigned group discussions during learning. The learning strategy used by the teacher in group discussion assignments is the cooperative learning strategy. Students work together in their study groups to complete the assignments the teacher has given them. Heterogeneity of study groups that favor cooperation, can train and accustom students to learn to respect and tolerate differences that exist between themselves and their peers in terms of ethnicity, religion, social strata, or abilities. 


\section{REFERENCE}

Abdullah, Masykuri, Pluralisme Agama dan Kerukunan dalam Keragaman Jakarta: Penerbit Buku Kompas, 2001.

Aunillah, Nurla Isna. Panduan Menerapkan Pendidikan Karakter di Sekolah. Yogyakarta: Laksana, 2011.

Badan Litbang dan Diklat Kementerian Agama, Toleransi Beragama Mahasiswa (Studi tentang Pengaruh Kepribadian, Keterlibatan Organisasi, Hasil Belajar Pendidikan Agama, dan Lingkungan Pendidikan terhadap Toleransi Mahasiswa Berbeda Agama Pada 7 Perguruan Tinggi Umum Negeri) Cet. I; Jakarta: Badan Litbang dan Diklat Kementerian Agama, 2010.

Casram. "Membangun Sikap Toleransi Beragama dalam Masyarakat Plural", Wawasan: Jurnal Ilmiah Agama dan Sosial Budaya 1, no. 2 (2016), h. 187-198.

Kementerian Pendidikan dan Kebudayaan, Rencana Strategis Kementerian Pendidikan dan Kebudayaan 2015-2019 Jakarta: Kemendikbud, 2015.

Kementerian Pendidikan Nasional, Desain Induk Pendidikan Karakter Jakarta: Kemendiknas, 2010.

Kementerian Pendidikan Nasional, Panduan Pelaksanaan Pendidikan Karakter (Jakarta: Kemendiknas, 2011.

Mulyasa, E., Manajemen Pendidikan Karakter Jakarta: PT. Bumi Aksara, 2013.

Munawar, Said Agil Husni Al-, Fikih Hubungan Antar Agama,Jakarta: Ciputat Press, 2003.

Shihab, Alwi, Islam Inklusif: Menuju Sikap Terbuka dalam Beragama Bandung: Mizan, 1997.

Tilaar, H.A.R., Multikulturalisme, Tantangan-Tantangan Global Masa Depan dalam Transformasi Pendidikan Nasional Jakarta: PT. Grasindo, 2004.

Tim Penyusun, Ensiklopedi Nasional Indonesia Jilid XVI Jakarta: Cipta Adi Pustaka, 1996.

Zubaedi. Desain Pendidikan Karakter: Konsepsi dan Aplikasinya pada Lembaga Pendidikan. Cet. II; Jakarta: Kencana, 2012.

\section{Internet Sources}

Cipto, Hendra, "Kisah Murid SD Bandar Narkoba, Sebulan Jadi Buron Polisi”, Kompas Online. $13 \quad$ September 2018. https://regional.kompas.com/read/2018/09/13/07000091 (12 November 2018).

Lathif, Akhmad Nazaruddin, "Kekerasan terhadap Siswa SD terjadi di Kudus", AntaranewS.com, 31 Juli 2017. https://www.antaranews.com/berita/643693 (12 November 2018).

Nay, Rivando, "Sekolah Negeri di Papua Larang Siswi Pakai Kerudung", Sindonew.com, $21 \quad$ Agustus 2014. https://daerah.sindonews.com/read/893817/26/sekolah-negeri-di-papua-larangsiswi-pakai-kerudung-1408626778 (12 November 2018). 


\section{Interview Sources}

Diana Lumban Gaol (55 years), Head of SDN Inpres 6.88 Perumnas 2 Jayapura, Interview, Jayapura, March 25, 2019.

Kristina P. Parirak (40 years), Class $5 \mathrm{C}$ teacher at SDN Inpres 6.88 Perumnas 2 Jayapura, Interview, Jayapura, March 252019.

Yulius Pius Nainggolan (35 years), Class 5 A Teacher at SDN Inpres 6.88 Perumnas 2 Jayapura, Interview, Jayapura, March 26, 2019. 